This item was submitted to Loughborough's Research Repository by the author.

Items in Figshare are protected by copyright, with all rights reserved, unless otherwise indicated.

\title{
Banal nationalism and the imagining of politics
}

PLEASE CITE THE PUBLISHED VERSION

http://www.palgrave.com/gb/book/9781137570970

\section{PUBLISHER}

(c) Palgrave Macmillan

\section{VERSION}

AM (Accepted Manuscript)

\section{PUBLISHER STATEMENT}

This book chapter was accepted for publication in the book "Everyday Nationhood: Theorising Culture, Identity and Belonging after Banal Nationalism" and the definitive published version is available at https://www.palgrave.com/gb/book/9781137570970

\section{LICENCE}

CC BY-NC-ND 4.0

\section{REPOSITORY RECORD}

Billig, Michael. 2017. "Banal Nationalism and the Imagining of Politics". figshare. https://hdl.handle.net/2134/23381. 
Banal nationalism and the imagining of politics

\section{Michael Billig}

It would be absurd to pretend that all the arguments of Banal Nationalism have been confirmed by the events that have occurred globally since the book was first published over twenty years ago. As I will suggest in this chapter, some of the book's weaknesses and its over-simplifications have, in fact, become clearer over time. Nonetheless, one central theme has been reinforced and this is shown in all the chapters of the present volume. The authors take for granted that the issue of nationalism remains important. It was different when Banal Nationalism first appeared. The fashion then was for social scientists to claim that the world was moving inexorably towards a global, post-national age. Foremost among the theorists of globalization was the sociologist Ulrich Beck. He criticised Banal Nationalism because it concentrated on nationalism and ignored 'banal cosmopolitanism', thereby being, in his words, 'selective to the point of distortion'. At the start of the twenty-first century any signs of banal nationalism were, according to Beck, 'only islands in an overwhelming river of banal cosmopolitanism’ (Beck and Willms, 2003, p. 37).

Nationalism and the world of nation-states has not withered away. In the past twenty years there have been massive shifts in populations across national borders, but this has not meant that those borders have been trampled down. Quite the contrary, within the countries to which the migrants have been fleeing, there has been pressure to strengthen borders. Generally boundaries continue to be policed, as well as to be contested both politically and militarily. The boundaries within the European Union might have been relaxed but those around the Union have been strengthened to exclude migrants. According to a recent book, the number of border walls in the world has increased. In 1989, there were fifteen border 
walls but by 2016 there were seventy. The number of deaths at borders has been rising, reaching record figures in 2015 (Jones, 2016). The new president of the United States campaigned for a wall to be built along his nation's border with Mexico. All this building of border walls and the heightened concern for boundaries is happening at a time when global trade and international travel are increasing.

Beck and others were mistaken when they assumed that global forces were antithetical to the particularity of nations and that as the former increased so inevitably the latter would decline. None of the contributors to this book have found it difficult to identify the existence of nationalism in the modern world. Their examples are to hand; they have not had to search for increasingly rare islets that have not yet been submerged by the rising waters of cosmopolitanism. Nor have they needed to start their chapters by justifying that they are taking the topic of nationalism seriously. As was suggested in Banal Nationalism, the world of nation-states has historically been an international world, for internationalism rests upon nationalism and vice versa. In this spirit, Craig Calhoun writes that 'forgetting the international character of nationalism is conducive to illusory notions of how globalization will affect nationalism’. He is rightly baffled by ‘how many people have imagined that globalization will simply replace nationalism with a universal, cosmopolitan consciousness'.

A number of the chapters highlight the links between nationalism and internationalism. Atsuko Ichijo provides an excellent empirical example when he examines how UNESCO included cooking as a protected cultural heritage. Ijiko notes the contradiction between UNESCO's position as an organization promoting universal values and its desire to promote the value of particular cultures. UNESCO operates within a national context: it encouraged official bids from the nation-states of Japan and France that parts of their respective culinary cultures be granted the status of protected cultural heritage. The contradictory position of UNESCO is hardly surprising. Its parent organization, the United 
Nations, is an international organization devoted to universal aims, while being comprised of individual nation-states. In consequence, the UN's internationalism is inextricably connected with the nationalism of established, recognized nation-states.

One of the main themes of Banal Nationalism was that signs of nationalism can be too familiar to be noticed. Whereas ordinary citizens may fail to observe the national symbols on the stamps that they are affixing to their letters or on the banknotes that they are spending in shops, it is less forgivable that social theorists should routinely be so unobservant. Social scientists have concealed the nationalism of Western nations by labelling it positively as 'patriotism', which they contrast favourably, but unjustifiably, with the 'nationalism' of others. As Calhoun comments, Banal Nationalism argued that ordinary people and social theorists have shared common blind-spots and that the book drew attention to signs of nationalism that often pass unrecognized. However, if such signs are 'often' unnoticed that does not mean that they are always so. Shanti Sumartojo makes the very reasonable point that from time to time individuals can notice the signs that they generally overlook - becoming, for instance, suddenly aware of the nationalist meaning of a road name on a well-travelled, familiar route. She notes that Banal Nationalism did not attempt to say how such episodes of sudden, individual recognition might occur. The book, of course, had its own blind-spots.

Before proceeding to discuss some of Banal Nationalism's other simplifications, it might be helpful to discuss what I believe to be a misunderstanding. This comes in the chapter by Ivana Spasić. She writes about the Serbia and she claims that the concept of 'banal nationalism' is, at the very minimum, inappropriate for understanding the Serbian situation. This is because the notion of 'banal nationalism', at least as outlined in my book, contains ethnocentric presuppositions, which express a Western bias against the non-Western world and against countries such as Serbia. This is an important charge that deserves to be examined. 
Spasić claims that in Banal Nationalism I was arguing that there were two distinct types of nationalism - banal nationalism and hot nationalism. According to Spasić, I equated banal nationalism with the nations of the West and hot nationalism with the non-Western world or with nations like Serbia that are situated on the 'semi-periphery'. She suggests that Banal Nationalism unequivocally condemned Serbian nationalism as non-banal nationalism and thereby sharply distinguished it from the banal nationalism of established nations. The result was that book expressed pro-Western assumptions that are tantamount to 'orientalism'. Spasić suggests that my preface to the Serbian edition of Banal Nationalism represents a change of thinking, for there I contemplated the possibility of Serbian banal nationalism.

I do not wish to dispute Spasić's observations about Serbian politics about which she knows far more than I do. However I would wish to dispute her interpretation of Banal Nationalism. I was arguing that the established nations of the West are deeply nationalist although their citizenry and sociological theorists often overlook this nationalism. Unfortunately, Spasić, in offering quotations to suggest that I was biased in favour of Western nations, sometimes quotes from the views that I was criticising in Banal Nationalism rather than those that I was upholding. Certainly I was not suggesting that the nations of the West were only nationalist in a banal sort of way. When I was writing Banal Nationalism, the British government was engaged militarily in Northern Ireland with Irish nationalists, who wanted the province to secede from the United Kingdom. In the book I criticised the ideological and theoretical bias which led only to the secessionists being labelled as 'nationalist'. The British government typically was not called 'nationalist', although it used force 'in the interest of maintaining, rather than challenging, present national boundaries' (Billig, 1995, p. 48). I was seeking to expose the ideological blindness which routinely calls politics aimed at altering nationalist boundaries 'nationalist', but which equally routinely withholds the same label from politics aimed at maintaining those same boundaries. 
Banal Nationalism aimed to apply the word 'nationalism' to the processes, often unnoticed, by which established nation-states are re-produced day-by-day. Spasić is correct to suggest that the processes of re-producing a nation-state differ from those involved in producing or creating the nation-state in the first place. The book assumes that the original formation of most nation-states, which have become established over time, was violent and backed by imaginative and highly conscious declarations about the nature of the state, its people and its claimed territory. This is certainly true of the United States of America, France, Italy, the United Kingdom and so on. When Banal Nationalism was originally written, Serbia was in the process of being produced, rather than being re-produced. If there is a difference between the first edition Banal Nationalism and the preface for the Serbian edition, it is that Serbian history has moved on. From being a nation, which was in the violent process of being produced, Serbia by 2009 was becoming a nation-state which will be banally re-produced.

I believe that Spasić over-simplifies Banal Nationalism when she presents it as suggesting that the processes of banal nationalism are typically confined to the West and that the nationalism of the rest of the world is non-banal. It was a major theme of Banal Nationalism that the ideology of nationalism is international - indeed, global. In this respect, 'ideology’ denotes the sorts of beliefs which seem so obvious - so natural - to those who live in a particular age that they require, to use Melissa Aronczyk’s phrase, few narratives of justification. For the last hundred years, it has been taken for granted, or treated as commonsense, that 'nations' exist and that a world divided into independent nation-states is 'natural'. We imagine that the world was always like this, although historically nation-states belong to the modern era. Particular nations, especially those that have not established their separate independence, might produce their own particular narratives of justification to support their claims for statehood, but nationhood per se today does not require justification. Moreover, as 
argued in Banal Nationalism, the belief in the 'naturalness' of nations and in the world of nations is itself global: it is not confined to specific continents.

That being so, banal nationalism, as one of the means by which established nations are re-produced, will not be confined to the nation-states of the west. It is likely to be found in any established or establishing state wherever it might be situated. Subsequent researchers have been able to find instances of banal nationalism across different continents. Crawford Young (2004) writes of the dozens of banal ways in which the new nations of Africa subliminally communicate nationhood through their flags, currency, postage stamps, identity cards and so on (see also Ndlovu-Gatsheni, 2011, and Fuller, 2008, for further African examples). Banal nationalism has been observed in Iran (Elhan, 2016), Syria and Jordan (Phillips, 2011) and Argentina (Benwell and Dodds, 2011; Benwell, 2014). If Serbia is part of the 'semi-periphery', then Turkey, straddling Europe and Asia, might be thought to be semisemi-peripheral. Nevertheless, researchers have found in the Turkish press analogous forms of banal nationalism as can be seen in the British press (Yumul and Özkırıml, 2000; Kös and Y1lmaz, 2012).

Of course, it might be argued in defence of Spasić that such investigations have expanded the concept of 'banal nationalism' beyond what I had intended in Banal Nationalism. Significantly, the researchers, who have found African, Asian and South American forms of banal nationalism, do not present their findings as if they are contradicting what had been argued in that book. Phillips claims to show that 'the everyday reproduction of nationalism which Billig identified in the West can be successfully adapted and transposed onto Syria and Jordan’ (2011, p. 3). According to Phillips, Banal Nationalism argued that 'the reproduction of nations in the West takes two forms: the conscious, overt flag-waving, such as 4th July parades in the USA, and the banal, un-waved flags that hang 
unnoticed on public buildings and outside houses' (p. 11). This I believe takes us to the centre of Spasić's dissatisfaction with, and possible misunderstanding of my 1995 book.

According to Spasić, I suggested in Banal Nationalism not only that banal nationalism is principally confined to the nations of the West, but also that this is the principal form of nationalism to be found in the West and that very different forms of nationalism exist outside of the West. She writes that in my book 'the dichotomy banal/non-banal is basically framed as Us/Them' and that 'some people have one, others have the other; "We” have this one, “They” (and some stray members of “Us”) have the other'. However, as Phillips’ quotation suggests, Banal Nationalism did not assert that the Western nations have a single form of nationalism, but that nationalism in established states, whether of the West or elsewhere, takes two forms - the banal and the non-banal. Indeed, the book argued that banal nationalism is the backdrop for more overtly nationalist episodes in the West.

That is why Banal Nationalism connected unwaved US flags with the highly nationalist passions of the first Gulf War; and British banal nationalism with the speedy mobilization of the British public in support of the Falklands/Malvinas war. As such, banal nationalism, far from being innocently peaceful, is the precondition for nationalist violence committed by established nations. Since 1995, the world has seen the US-led invasions of Iraq and Afghanistan, not to mention interventions by the USA and Russia in Syria. All these campaigns have been accompanied by outpourings of nationalism within the established nations that are doing the intervening and the invading. The argument of Banal Nationalism was that the populations of such countries could not be mobilized so quickly and so successfully for sudden military campaigns without the steady existence of banal nationalism in between the episodes of hot nationalism. 
There are, nevertheless, a number of over-simplifications in Banal Nationalism which later researchers, including those in the present volume, have commented upon. As can often happen, social scientists, who aim to draw attention to phenomena that have previously been overlooked, can emphasise their case rhetorically by presenting clear exemplars. In consequence, they can end up with illustrations that resemble 'ideal types', rather than examining the complexities of actual cases as they messily unfold in real life. Banal Nationalism was a comparatively short book of less than two hundred pages. So, simplifications can be expected, although that does not excuse them. It is the task of subsequent investigators to fill in the complex details. I now think that the one chapter, which aimed to provide an empirical investigation to support the theoretical ideas of the book, considerably over-simplified matters. As critics have noted, the one-day study of newspapers failed to emphasise sufficiently the English dimension of the papers that were analysed. It did not distinguish adequately between the banal re-production of England as compared with that of Britain, let alone the United Kingdom. In addition, I ignored the newspapers of Scotland, Wales and Northern Ireland, failing to discuss how such newspapers might portray, both banally and non-banally, the complex national contexts in which they were published. Such points have been made by subsequent critics, whose observations contribute to understanding the complex forms that banal nationalism can take in nations within nations (for example, Law, 2001; Rosie et al, 2004; MacInnes, 2007 et al; Skey, 2009).

Today, I would concede that the day-study of newspapers contain obvious gaps and also that the analysis itself often failed to probe the rhetorical complexities of the phenomenon that it aimed to demonstrate. The book argues that there is a contrast between hot nationalism and banal nationalism - metaphorically illustrated as the contrast between the waved and the unwaved flag. But this contrast, which may have made the basic theme more understandable, is too stark. It implies that at one moment there are no waved flags and at the 
next all is a blur of waving flags. As Skey (2009) has noted, there are gradations between hot and cold nationalism and that the gradations of temperature are better represented by talking about heating and cooling nationalist temperatures. Generally the social sciences benefit by using verb phrases ('heating and cooling nationalist temperatures') rather than noun phrases ('hot and cold nationalism') to describe processes brought about by human actions (Billig, 2013). Using the phrases of heating and cooling nationalist temperatures emphasises the gradations in between the extremes. Hopefully such phrases will encourage investigators to point to the ways that actors might be heating up or cooling down moments of nationalism.

The inadequacy of just using the concepts of 'hot' and 'cold' nationalism does not stop there. It is a mistake - and a mistake to be found in Banal Nationalism - to suppose that each moment in the history of nationalism can be summarised by a single temperature. The heating and cooling of nationalism can occur at the same time in the same place. If I had looked more carefully at my single day survey of the English press, I would have found this. I presented the survey as representing a moment of banal nationalism. The day's papers also described the successes and failures of the nation's sportsmen and women. The items were encouraging little cheers or feelings of minor disappointment. The nationalist temperature was warming on some pages of the press as it was cooling on others: indeed, it might be moving in both directions on the same page and even within the same paragraph.

In this volume, Lukasz Szulc takes this idea further. He notes how lesbians and gays using LGBTQ websites in Poland and Turkey employ the language of banal nationalism in order to 'domesticate' such sites. In illustrating this, Szulc connects the complexity of nationalism's temperature with the emphasis in Banal Nationalism on top-down signs of nationhood. By contrast, Szulc looks at the way that ordinary people can challenge and reinterpret official signs and then use their reinterpretations banally. It should be added that since the publication of Banal Nationalism there has been of growth of research examining 
episodes of such bottom-up nationalism. This volume contains a number of such studies besides Szulc's. Those who study nationalism in this way sometimes wish to distinguish what they call ‘everyday nationalism’ from ‘banal nationalism’. In my view, analysts of nationalism do not need to choose between taking the one approach or the other, as if there is a theoretical zero-sum game at work. As Szulc's chapter illustrates, it is possible to combine creatively the study of everyday actions that re-produce and re-imagine the nation, with an awareness of how that re-imagined nation can also be re-produced banally. Investigators, therefore, should try to avoid assuming that the reality of 'banal nationalism' must reflect the sorts of simplifications to be found in the book of the same name and that anything more complex should be taken as evidence for the non-existence of banal nationalism. As Szulc comments there is still work to be done on banal nationalism. In particular, as he comments, there remains amazingly little interest in researching the banal nationalism of the United States.

There is a simplification of emotions in Banal Nationalism, relating to the contrast between banal and hot nationalism. Calhoun, in his chapter, rightly claims that there is a certain 'flatness' in my characterisation of banal nationalism. Partly this comes from concentrating on the unnoticed, banal aspects of nationalism - the weather maps, the nationally deictic use of the definite article (le président, the prime minister, el país, ha-aretz and so on), and all the other barely noticed but ever present signs of nationhood. These are not matters to stir the heart but that is precisely the point. However, nationalism, as Calhoun points out, cannot rest solely upon such pallid factors. It requires, to use Calhoun's phrase, 'an imaginary', so that each nation imagines itself to be unique. And in imagining itself to be unique, the particular nation is just like all other nations, imagining themselves to be unique.

Nor is hot nationalism circumscribed by the waving of the flag - as if there is only absence of emotion or feelings of intense enthusiasm with no points in-between. There are 
other uses of the flag beyond being waved or not waved. I regret that I did not comment upon the common, international trope of the flag draped over the coffin. Here the emotions can be complex: sadness, respect, solemnity and so on. In the context in which the image of the coffin-draped flag is often displayed, the image can also be interpreted as expressing 'necessary' sacrifice and the 'just' desire for revenge. The familiarity of the visual trope means that its emotional semantics do not need to be specified each time the image is presented. Distant observers within the nation, seeing the image by means of television, internet or newspapers, can respond with appropriate emotion - not that all will do so.

Banal Nationalism did not discuss in detail how the banally reproduced signs might be received - who will fail to notice them, who will register approval and who will react with disapproval (even outrage). The work did not aim to detail individual differences, or even communal differences. If the book expressed a tendency to suppose that officially produced images, phrases and signs will always be accepted unthinkingly then this is regrettable. The present volume contains two studies which dramatically show how an official governmental policy on citizenship - the official imagining of the nation - can be rejected by many members of the nation. Manolis Pratsinakis and Gesine Wallem discuss how citizens can dissent in their everyday actions from the official definitions of nationhood. These citizens are not 'nationalists' in the traditional sense of the term because they do not wish to secede from their nation, or to re-draw its boundaries or to base politics around the idea of the nation. Instead, they wish to exclude from the nation some who officially qualify for their nation’s citizenship.

Pratsinakis and Wallem present evidence from two populations, living in different countries but sharing similar reactions. Pratsinakis looks at the reactions of native Greeks to incomers from the former Soviet Union whom the Greek government has declared to be ethnically Greek. Wallem examines a similar situation in Germany. In both cases, the 
incomers are not accepted as fellow citizens by many of the natives who see them primarily as 'Russians'. They criticise the incomers for speaking Russian among themselves, for behaving in so-called typically ‘Russian’ ways, and generally for being 'really’ Russian, rather than 'really' Greek or German. To use a concept that Aronczyk uses in her chapter, these native inhabitants see their governments as committing 'categorical treachery' when they accepted these essentially 'foreign' incomers as if they were 'properly' Greek or German. This nationalist complaint represents what analysts have termed 'everyday nationalism', as compared with the sort of top-down official symbols of nationhood discussed in Banal Nationalism.

Nevertheless, in crucial ways this sort of everyday nationalism rests upon an unexamined, banal assumption: namely that everyone, or virtually everyone, in the world of nations belongs 'properly' to a particular nation. The incomers, according to the complainants, have no place here in 'our' homeland because they are properly 'Russian'. The complainants do not have to spell out their ideological reasoning from first principles. The deep logic that nations can and should exclude those who do not belong is part of a commonsense that is accepted from nation to nation. These Greek and German complainants can make their arguments with accusatory stereotypes, using the unexpressed, exclusionary assumptions of nationalism - not just 'our' nationalism but nationalism internationally - to justify their specific complaints about 'them'. It is these deep assumptions about belonging and, most importantly, about not-belonging to nations that, in a time of mass migration, can leave millions in makeshift, exposed camps, unwelcome in the countries to which they have fled and unable to return to their so-called 'proper' countries. The leaders and populations of other nations wring their hands: these unfortunates do not belong 'here' with 'us', they say. To demonstrate 'our' magnanimity and the goodness of 'our' great nation, 'we' will accept a 
few - a very few - but all the others in their millions must go elsewhere, preferably back to 'their' own lands where 'they' supposedly belong but where they have suffered so much.

Calhoun is surely correct in claiming that the imagining of nations can be performed imaginatively. He writes that 'the idea of social imaginaries is precisely a bridge between the objectively recurrent and the subjectively enacted.' He also suggests that Banal Nationalism was over-critical of nationalism. Far from being uniformly pernicious, nationalism can be integral to positive projects. Democracy, for example, depends upon notions of the nation, or the national people, making its choice. In this regard, it rests today upon national 'imaginaries'. But here is the problem: the assumptions of nationhood and the dominance of the national 'imaginary' have not just produce exclusive communities but they have, in effect, blocked out alternative ways of imagining the political past and present.

Recently I have been examining the annual celebration in the Portuguese parliament commemorating the 1974 overthrow of dictatorship (Billig and Marinho, in press). This is not an example of banal nationalism, for metaphorically the flag is waved on these occasions, as 'we' celebrate 'our' history and 'our' great triumph. Such a ceremony is what the classical rhetoricians called 'epideictic'. Modern rhetorical analysts claim that national epideictic ceremonies affirm a sense of collective belonging (for example, Perelman and OlbrechtsTyteca, 1968; Condit, 1985). In the Portuguese ceremony the national context dominates the ceremony and both banal and imaginative rhetoric are to be found intermingled. What Calhoun calls the national 'imaginary' overwhelms any other form of imagining politics thereby constraining, as well as expanding what can be politically imagined.

The Portuguese deputies, as they celebrate the historic overthrow of the Salazarist dictatorship, typically pursue current partisan politics. Sometimes in these celebrations speakers from the right will dispute with those from the left about the term 'the people' ( $o$ 
povo). Both, however, will accept the nationalist meaning of the term: in the context of the celebration 'the people' refers to the people of Portugal. In the 2010 ceremony, a speaker from the right was talking about his party’s view on re-writing the formal constitution of Portugal. The speaker explicitly criticised the left-wing concept of o povo, which refers to the unprivileged mass as contrasted with the privileged few. The speaker claimed that all Portuguese belonged to o povo, rich and poor, the shareholder as well as the worker. A deputy from the Communist Party then interrupted, calling out: 'Strike out the shareholder!' Left-wing deputies responded with laughter.

We can ask why the left-wing deputies laughed. At its minimum such laughter indicates that the left was not seriously advocating that the constitution should be revised to exclude shareholders from citizenship. If this were the actual policy, then cheers and applause, not laughter, could be expected. The intervention and the accompanying laughter illustrates the extent to which a former dream of universal unity (the dream of workers of the world uniting) has become nationalised in the twenty-first century. Now the thought of removing shareholders from the nation, like a Freudian fantasy, can only be expressed as a joke, rather than as a serious desire.

This illustrative example might seem unimportant but it expresses something that is today so familiar, so banal, as to be hardly worth noticing. The term 'the people' has been coopted nationally within the world of nations, and has been correspondingly emptied of its non-national, even anti-national, class-based meaning. An imagined politics, not based around the imagined nation, is virtually unimaginable. Thus, the so-called national ‘imaginary’ also represents a restriction of political imagination. In this respect, nationalism is not a disappearing island about to be overcome by the tidal flow of internationalism. It remains the dominant political ideology of today, determining what politics is to be seriously practised and what can only be non-seriously imagined. 
References

Beck, U. and J. Willms (2003) Conversations with Ulrich Beck (Cambridge: Polity Press).

Benwell, M.C. (2014) 'From the Banal to the Blatant: Expressions of Nationalism in Secondary Schools in Argentina and the Falkland Islands', Geoforum, 52, 51-60.

Benwell, M.C. and K. Dodds (2011) ‘Argentine Territorial Nationalism Revisited: The Malvinas/Falklands Dispute and Geographies of Everyday Nationalism’, Political Geography, 30, 441-9.

Billig, M. (1995) Banal Nationalism (London: Sage Publications).

Billig, M. (2009) Banalni Nacionalizam (Belgrade: Biblioteka XX).

Billig, M. (2013) Learn to Write Badly: How to Succeed in the Social Sciences (Cambridge: Cambridge University Press).

Billig, M. and C. Marinho (in press) The Politics and Rhetoric of Commemoration (London: Bloomsbury Press).

Condit, C.M. (1985) 'The Functions of Epideictic: the Boston Massacre Orations as Exemplar', Communication Quarterly, 33, 284-99.

Crawford Young, M. (2004) 'Revisiting Nationalism and Ethnicity in Africa’, James S. Coleman Memorial Lecture Series, University of California, http://escholarship.org/uc/item/28h0r4sr

Elhan, N. (2016) 'Banal Nationalism in Iran: Daily Re-production of National and Religious Identity’, Insan ve Toplum, 6, 119-36. 
Fuller, H.C. (2008) 'Coinage in Ghana and symbols of Nkruma', Nations and Nationalism, $14,520-41$.

Jones, R. (2016) Violent Borders (London: Verso).

Kös, A. and Y1lmaz, M. (2012) 'Flagging Turkishness: the Reproduction of Banal Nationalism in the Turkish Press', Nationalities Papers, 40, 909-25.

Law, A. (2001) 'Near and Far: Banal National Identity and the Press in Scotland', Media, Culture and Society, 23, 299-322.

MacInnes, J., M. Rosie, S. Condor, P. Petersoo and J. Kennedy (2007) 'Where is the British National Press?’, British Journal of Sociology, 58, 185-206.

Ndlovu-Gatsheni, S.J. (2011) 'The World Cup, Vuvuzelas, Flag-waving Patriots and the Burden of Building South Africa', Third World Quarterly, 32, 279-93.

Perelman, C. and L. Olbrechts-Tyteca (1969) The New Rhetoric (London: University of Notre Dame Press).

Phillips, C. (2011) Everyday Arab Identity: the Daily Reproduction of the Arab World (London: Routledge).

Rosie, M., J. MacInnes, P. Petersoo, S. Condor and J. Kennedy (2004) 'Nation Speaking unto Nation? National Identity and the Press in the Devolved UK', Sociological Review, 52, 437-58.

Skey, M. (2009) 'The National in Everyday Life: a Critical Engagement with Michael Billig’s Thesis of Banal Nationalism', Sociological Review, 57, 331-46.

Yumul, A. and U. Özkırımlı, (2000) 'Reproducing the Nation: 'Banal Nationalism' in the Turkish Press', Media Culture Society, 22, 787-804. 